\title{
A morphometric and morphological study of the lungs of rabbits after unilateral pneumonectomy
}

\author{
EDWIN S. BOATMAN
}

From the Department of Environmental Health, School of Public Health, University of Washington, Seattle, Washington, USA

Boatman, E. S. (1977). Thorax, 32, 406-417. A morphometric and morphological study of the lungs of rabbits after unilateral pneumonectomy. A study was made to determine the changes occurring in the contralateral lung of adult rabbits as a result of left pneumonectomy.

Stereological procedures for light microscopy and for electron microscopy were used to quantitate the changes. Lungs from control rabbits, ranging in body weight from 1.0 to $9.0 \mathrm{~kg}$, were also analysed. Resin corrosion casts of left and right lungs were prepared.

Left pneumonectomy causes the volume of the right lung to increase to the total paired lung volume in about four weeks. Total surface area, while increasing directly with lung volume in control rabbits, increased as two-thirds of the lung volume after pneumonectomy. In some right lungs there appeared to be an increase in the number of alveoli. Mean linear intercepts for control lungs were fairly constant, but the volume density of alveolar ducts increased with age.

In pneumonectomised animals, mean air-space diameter of the right lung increased by about $25 \%$ and the volume density of alveolar ducts by $22-33 \%$. The volume density of alveolar wall tissue decreased by about $30 \%$.

The average number of alveoli $/ \mathrm{cm}^{3}$ for whole lungs was $2 \cdot 31 \pm 0 \cdot 46 \times 10^{6}$, whereas for right lungs eight weeks or more after pneumonectomy it was significantly less $\left(1 \cdot 70 \pm 0.38 \times 10^{6}\right)$.

Morphometry by electron microscopy revealed slight changes in the components of the alveolar septum and a reduction in the thickness of the air-blood barrier.

The overall effect of left pneumonectomy was mainly one of a compensatory increase in the volume of the right lung with dilatation of alveoli and of alveolar ducts.

During the normal growth and development of the lungs, the requirements for new respiratory tissue to fill the space created by a gradually expanding chest wall is met by an orderly lengthening of respiratory passages and an increase in the number and size of the alveoli. Pneumonectomy, however, creates a different set of conditions in that a significant volume of the thoracic cavity is suddenly deprived of lung tissue. How then does the remaining lung respond and how is the interdependence of function and structure maintained? Not surprisingly, this question has been posed (Haasler, 1892) and investigated experimentally for over 80 years. Functional, biochemical, and morphological aspects have been explored in both man and a variety of animals. A singularly controversial area has been whether the alveoli of the remaining lung enlarge after pneumonectomy or increase in number in concert with a rapidly increasing lung volume. Quite early, it was appreciated that alveolar size may not be uniform throughout the parenchyma and efforts to obtain quantitative results were made (Longacre and Johansmann, 1940).

Rienhoff et al. (1935) studied the effects of pneumonectomy in the dog. From observations based on lung casts and celloidin sections it was concluded that the compensatory changes were due to a marked dilatation of respiratory units.

Bremer (1937) found, in a comparison of kittens with adult cats, that the structural changes taking place in the remaining lung were determined by the capacity for further body and lung growth and were thus age dependent. Longacre and Johansmann (1940) compared puppies with adult dogs and came to a similar conclusion.

In these studies dimensional changes were determined by counting and measuring alveoli. The first comprehensive morphometric study was conducted by Seŕy et al. (1969). They found that pneumonectomy 
in both young and adult rabbits produced enlargement of existing respiratory units without evidence of a numerical increase. In contrast to this, Gnävi et al. (1970) showed in guinea-pigs that in growing animals growth of the remaining lung was similar to postnatal growth; in the adult, the response was limited to dilatation of the residual tissue.

Two recent pneumonectomy studies in rats, one by Buhain and Brody (1973) who found no evidence of alveolar multiplication, and the other by Nattie et al. (1974) who showed that surface alveoli increased in number while the more central ones did not, point to the subtle changes that may be uncovered depending upon the procedures employed. One important factor associated with the use of the rat is that, in this animal, alveoli may continue to increase in number throughout life (Donaldson, 1924).

The purpose of the present study is (1) to evaluate in the adult rabbit the growth of the remaining lung after pneumonectomy, and (2) to identify the changes that may take place in this lung after exposure to an air-pollutant gas (ozone). Structural and dimensional changes in the parenchyma of the remaining lung were investigated by use of morphometry employing light and electron microscopy and by lung corrosion casts. This communication will deal with the first part of the study.

\section{Material and methods}

\section{ANIMALS}

Male New Zealand white rabbits, 2.5 to $3.0 \mathrm{~kg}$ in body weight (about 3 months of age), were used for the pneumonectomy and for morphometry. A further group of rabbits weighing $1.0 \mathrm{~kg}$ to $9.0 \mathrm{~kg}$ was used only for morphometry. Animals were kept in a controlled environment and fed a standard pellet diet, cabbage and water ad libitum.

\section{PNEUMONECTOMY}

With the animal under sodium pentobarbital anaesthesia, the left lung was removed. Animals were intubated and ventilated by bag inflation with $100 \%$ oxygen. An incision was made through the left fourth interspace, and the left main bronchus and pulmonary blood vessels were isolated, the vessels ligated and the lung removed. The incision was closed in layers and all of the air available to aspiration by syringe was withdrawn from the left pleural space. Ventilation with oxygen was continued for 20 minutes after closure. Animals were killed at periods ranging from 2 to 14 weeks after pneumonectomy.

\section{LUNG FIXATION AND PROCESSING}

Left lungs removed at operation and the corresponding right lungs removed at varying periods subse- quently were fixed and processed in an identical manner. The wet weights of the lungs were determined. Fixation was accomplished by tracheal or bronchial instillation of $0.11 \mathrm{M}$ s-collidine buffered $1.5 \%$ glutaraldehyde (pH 7.4, osmolality $300 \mathrm{mOsm} /$ $\mathrm{kg} \mathrm{H}_{2} \mathrm{O}$ ) maintained at a pressure of $20 \mathrm{~cm} \mathrm{H}_{2} \mathrm{O}$ with the lungs or lung immersed in a beaker containing buffered fixative. After 18 to 20 hours' fixation at $21^{\circ} \mathrm{C}$ the trachea was clamped and the volume of the lung was estimated by displacement.

Successive transverse slices of tissue, $4.0 \mathrm{~mm}$ thick, were obtained from all lobes and alternate slices (ranging from 1 to 3 ) were post-fixed in s-collidine buffered $1 \%$ osmium tetroxide stained en bloc with uranyl acetate and dehydrated in ascending concentrations of ethanol starting at $70 \%$. Lung slices were embedded face down in Epon 812 resin and polymerised at $60^{\circ} \mathrm{C}$ for 48 hours in flat moulds measuring $2.5 \times 3.5 \mathrm{~cm}^{1}$. In addition, six random blocks of tissue, $2 \mathrm{~mm}^{3}$, were embedded in resin and an ultrathin section was cut from each block by use of a Serval Ultramicrotome II and a diamond knife. Sections for light microscopy were cut at 1 to $2 \mu \mathrm{m}$ by the method of Boatman and Lowe (1971) and stained with azure II-methylene blue. Those tissue slices which were not post-fixed in osmium tetroxide were stored in buffered glutaraldehyde and used for the estimation of the volume density of non-parenchyma.

\section{MORPHOMETRIC ANALYSIS}

Light microscopic evaluation A plastic grid was superimposed on glutaraldehyde fixed $4.0 \mathrm{~mm}$ thick sections (Dunnill, 1962), which were observed under a dissecting microscope at $\times 10$ magnification, and the amount of non-parenchyma for each lung was estimated.

During the early part of the study the $1 \mu \mathrm{m}$ stained sections were examined by use of a Zeiss type 1 integrating eyepiece at final magnifications of $\times 200$ and $\times 320$. Later, the same sections were reviewed by the same observer at $\times \mathbf{2 0 0}$ and $\times \mathbf{4 0 0}$ using a Wild M501 automatic sampling stage microscope (Weibel, 1970a). Sections (from upper and lower lobes) were systematically covered in steps of $1120 \mu \mathrm{m}$ and the images were projected onto a square test-point lattice. Only one test point in the centre of the test screen was used according to the procedure of Burri et al. (1974). From a total of 500-700 point hits/section the relative volume densities of the following components were determined: (1) volume density of nonparenchyma $\left(\mathrm{V}_{\mathrm{vnp}}\right)$; (2) volume density of alveolar air space $\left(\mathrm{V}_{\mathrm{va}}\right) ;(3)$ volume density of alveolar septal

\footnotetext{
${ }^{1}$ After successive treatments in glutaraldehyde, osmium tetroxide, and embedding in resin, individual slices were photographed and the profiles were measured by planimetry to estimate changes due to shrinkage or swelling.
} 
tissue $\left(\mathrm{V}_{\mathrm{vt}}\right)$; and (4) volume density of alveolar ducts $\left(\mathrm{V}_{\mathrm{vad}}\right)$. The surface density of air space $\left(\mathrm{S}_{\mathrm{va}}\right)$ and the mean linear intercept $\left(\mathrm{L}_{\mathrm{m}}\right)$ were estimated by intersection counts (Tomkeieff, 1945). Since the mean linear intercept measurements included both air spaces, that is, alveolar and duct, measurements of individual alveolar profiles from $1.0 \mu \mathrm{m}$ sections of some control and post-pneumonectomy tissues were made by direct projection and tracings.

The number of alveoli in 10 random fields of a standard area was determined on each slide by the method of Dunnill (1962). Counting of alveoli by use of the Zeiss integrating eyepiece or by the Weibel grid was supplemented in some cases by counting alveoli in randomly circled areas on photographic prints made from negatives of $1.0 \mu \mathrm{m}$ sections and enlarged $\times 67$.

The total number of alveoli per lung $\left(\mathrm{N}_{\mathrm{A}}\right)$ was calculated by use of the Weibel-Gomez (1962) formula modified by Burri et al. (1974):

$$
\mathrm{N}_{\mathrm{va}}=1 . \underset{\beta}{\mathrm{NA}_{\mathrm{a}}{ }^{3 / 2} \text {, where } \beta=1.55 \text { and } \mathrm{N}_{\mathrm{A}}=} \quad \mathrm{N}_{\mathrm{va}} \times \mathrm{V}_{\mathrm{vp}} \times \mathrm{V}_{\mathrm{L} .}{ }^{*}
$$

The air space of the lung $\left(\mathbf{S}_{\mathrm{a}}\right)$ was obtained by use of the surface density of air-space $\left(\mathrm{S}_{\mathrm{va}}\right)$ multiplied by the volume of lung parenchyma (ie, total lung volume $\left(V_{L}\right) \times$ percentage of lung parenchyma $\left(V_{v p}\right)$ ).

Electron microscopic evaluation Ultra-thin sections from random blocks of tissue were mounted on 200 mesh carbon coated grids and photographed in a random manner with a Philips EM 201 in accordance with the procedure described by Weibel (1963). An average of 36 to 40 pictures were taken per lung on $35 \mathrm{~mm}$ film at a magnification of $\times 1120$. Positives of the films were analysed on a multipurpose test screen (Weibel, 1970b) consisting of 84 lines and 168 test points for point and intersection counting.

The parameters estimated were the volume densities of epithelium, interstitium, and endothelium and the arithmetic mean thickness of the air-blood barrier (Weibel, 1970b).

$* \mathrm{~N}_{\mathrm{va}}=$ number of alveoli $/ \mathrm{cm}^{3} ; \mathrm{NA}_{\mathbf{a}}=$ number of alveolat transections/ $\mathrm{cm}^{2} ; \mathrm{V}_{\mathrm{vp}}=$ volume proportion of lung parenchyma.
LUNG CORROSION CASTING

Casts of normal adult rabbit lungs and of the right lungs removed at various times after left pneumonectomy were prepared by the method of Tompsett (1970) using general purpose polyester resins. Penetration of the resin down the bronchial tree was stopped in the region of the respiratory bronchioles which, in the rabbit, are about $0.15 \mathrm{~mm}$ diameter. Tissue was removed from the casts by immersion in concentrated $\mathrm{HCl}$. Casts were trimmed under a dissecting microscope and airway diameters and interbranch distances were measured with a micrometer eyepiece.

\section{Results}

In our hands the survival rate after left pneumonectomy was about $80 \%$ and animals were usually eating normally within two to three days. Although most animals were killed at periods ranging from 2 to 14 weeks, two rabbits alive at 17 and 21 months are in good health and will be kept for an additional period.

\section{Morphometry}

\section{LIGHT MICROSCOPY}

The average volume proportion of non-parenchyma lung tissue obtained by analysis of $4.0 \mathrm{~mm}$ thick transverse slices of lung at a magnification of $\times 10$ was $11.9 \%$, whereas a study of $1.0 \mu \mathrm{m}$ stained sections at $\times 200$ gave a figure of $13.7 \%$. The latter figure was considered to be the more accurate estimate since at the higher magnification the differentiation of small airways, arteries, and veins from other tissue was more precise.

A comparison between thi use of a grid of 25 squares and a Zeiss integrating eyepiece for estimating the volume densities of various components of left lungs, based on total point 'hits' of between 500 and 700 , gave results that were not significantly different. Further morphometric values for left and right lungs are shown in Table 1. It is seen that an increase in body weight (growth) has a major influence on lung

\begin{tabular}{|c|c|c|c|c|c|c|c|c|}
\hline $\begin{array}{l}\text { No. of } \\
\text { animals }\end{array}$ & Lung & $\begin{array}{l}\text { Body wt } \\
\left(k_{g}\right)\end{array}$ & $V_{p}(m l)$ & $N_{v i,} \times 10^{-6} / \mathrm{cm}^{3}$ & $N_{a} \times 10^{-6}$ & $L_{m}(\mu m)$ & $V_{v a d} \mathrm{~cm}^{2} / \mathrm{cm}^{3}$ & $S_{a} m^{2}$ \\
\hline $\begin{array}{l}7 \\
2\end{array}$ & $\begin{array}{l}\text { Left } \\
\text { Left }\end{array}$ & $\begin{array}{l}2 \cdot 8 \div 0 \cdot 25 \\
4 \cdot 3\end{array}$ & $\begin{array}{l}13 \cdot 7 \pm 1 \cdot 8 \\
22 \cdot 5\end{array}$ & $\begin{array}{l}3 \cdot 1 \pm 0 \cdot 28 \\
2 \cdot 2\end{array}$ & $\begin{array}{l}43 \cdot 8 \pm 9 \cdot 62 \\
47 \cdot 3\end{array}$ & $\begin{array}{l}65 \cdot 9 \pm 6 \cdot 19 \\
72 \cdot 9\end{array}$ & $\begin{array}{l}0.29 \pm 0.03 \\
0.28\end{array}$ & $\begin{array}{l}0.712 \pm 0.12 \\
1.062\end{array}$ \\
\hline $\begin{array}{l}1 \\
1\end{array}$ & $\begin{array}{l}\text { Right } \\
\text { Right }\end{array}$ & $\begin{array}{l}2 \cdot 8 \\
4 \cdot 3\end{array}$ & $\begin{array}{l}30 \cdot 1 \\
43 \cdot 2\end{array}$ & $\begin{array}{l}2 \cdot 7 \\
1 \cdot 8\end{array}$ & $\begin{array}{l}80 \cdot 3 \\
79 \cdot 1\end{array}$ & $\begin{array}{l}64 \cdot 6 \\
76 \cdot 4\end{array}$ & $\begin{array}{l}0.33 \\
0.32\end{array}$ & $\begin{array}{l}1.610 \\
1.990\end{array}$ \\
\hline
\end{tabular}

Table 1 Some morphometric parameters of left and right control lungs (Weibel grid)

Top row data: Mean \pm SD. $V_{p}=$ lung volume corrected for $\%$ non-parenchyma; $N_{v a}=$ number of al veoli $/ \mathrm{cm}^{3} ; \mathrm{N}_{\mathrm{a}}=\varepsilon \mathrm{ksolute}$ number of alveoli; $\mathbf{L}_{\mathrm{m}}=$ mean linear intercept $; V_{\mathrm{vad}}=$ volume density of $:$ ! veolar ducts; $S_{\mathbf{a}}=$ total air-space surface area. 
volume, mean air-space dimensions $\left(\mathrm{L}_{\mathrm{m}}\right)$, and total air-space $\left(S_{a}\right)$, all of which increase. The lung volumes of the combined left and right lungs for the two body weights shown $(2.8 \mathrm{~kg}$ and $4.3 \mathrm{~kg})$ were $44.0 \mathrm{ml}$ and $66.0 \mathrm{ml}$ respectively. For an average body weight of $4.3 \mathrm{~kg}$ the total number of alveoli/whole lung was $126.0 \times 10^{6}$ with a mean linear intercept of $74.6 \mu \mathrm{m}$. Linear regression calculations indicated that total alveolar number $\left(\mathrm{N}_{\mathrm{a}}\right)$ and total air-space surface area $\left(S_{A}\right)$ correlated more closely with lung volume than with body weight. Photographs of portions of typical $1.0 \mu \mathrm{m}$ sections of a left lung and of a right lung eight weeks after pneumonectomy and with the corresponding morphometric data are shown in Figs. $1 \mathrm{a}$ and $\mathrm{b}$. Lung changes as a result of pneumonectomy caused a decrease in $V_{v a}$ and $V_{v t}$ and an increase in $\mathrm{V}_{\text {vad }}$ and $\mathrm{L}_{\mathrm{m}}$.

A comparison between three methods of estimating the average number of alveoli/10 fields/slide of a right lung removed 11 weeks after pneumonectomy

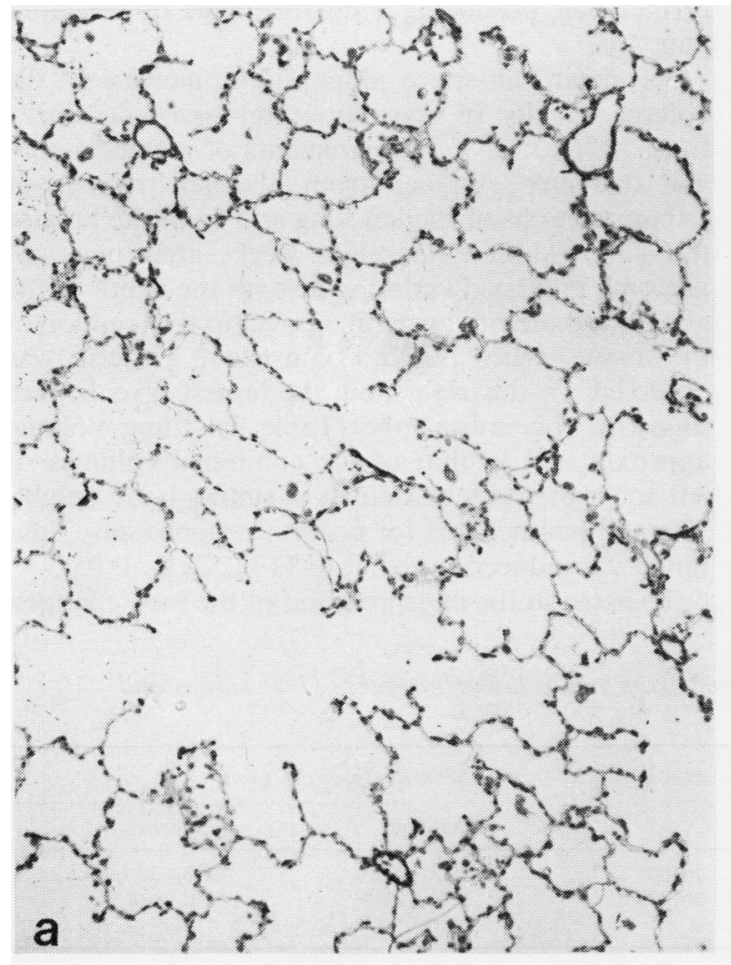

CONTROL

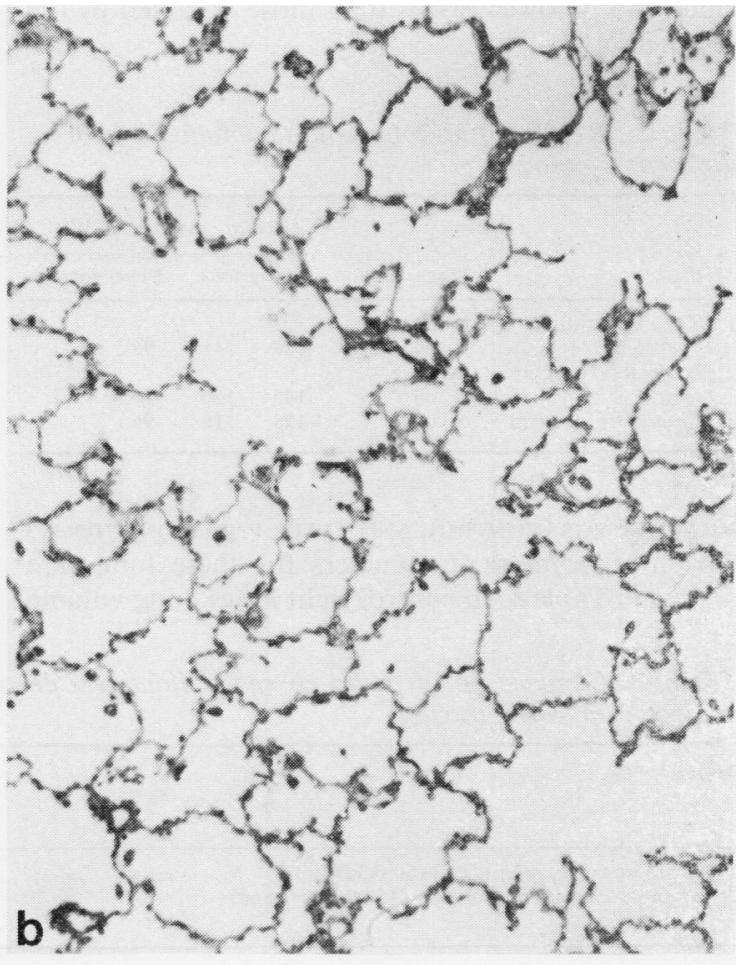

PNEUMONECTOMY

\begin{tabular}{|c|c|c|c|c|c|}
\hline & $\mathrm{W} \uparrow . \mathrm{Kg}$. & $v_{v a}$ & $v_{v t}$ & $V_{\text {vad }}$ & $\operatorname{Lm}(\mu \mathrm{m})$ \\
\hline CONTROL & $3 \cdot 4$ & $47 \cdot 4$ & $21 \cdot 2$ & $30 \cdot 2$ & $68 \cdot 8$ \\
\hline PNEUMONECTOMY & $3 \cdot 6$ & $39 \cdot 5$ & $15 \cdot 4$ & $40 \cdot 8$ & $95 \cdot 6$ \\
\hline
\end{tabular}

Fig. 1 Light microscopy of a random ficld of a section of $(a)$ control lung and $(b)$ a lung eight weeks after pneumonectomy. Stereological differences derived by morphometric analysis of random fields are shown in the appended table: $V_{v a}=$ volume density of alveolar air-space, $V_{r t}=$ volume density of alveolar septum, $V_{i u !}=$ volume density of alveolar duct, and $L_{m}=$ mean linear intercept. 
revealed no marked differences (Table 2). Use of a projected 16 square grid gave slightly higher alveolar counts. Alveoli in the upper lobe were slightly larger and, therefore, of a lower surface density $\left(\mathbf{S}_{\mathrm{va}}\right)$, ie, fewer in number, than in the lower lobe.

Air space dimensions calculated by the $\mathrm{L}_{\mathrm{m}}$ method (horizontal and vertical estimates) were compared with measurements obtained by tracing the outlines of individual alveoli. Both left and right lungs were used and the results are shown in Table 3. Dimensions obtained from tracings of projected alveoli yielded significantly lower values than those obtained by the $\mathbf{L}_{m}$ method.

Table 2 Results of alveolar counts obtained by three different methods

\begin{tabular}{|c|c|c|c|c|c|}
\hline \multirow{2}{*}{\multicolumn{2}{|c|}{ Method }} & \multirow[b]{2}{*}{ Magnification } & \multicolumn{3}{|c|}{ Alveolar count $/ \mathrm{cm}^{2} \times 10^{2}$} \\
\hline & & & \multicolumn{2}{|c|}{ Lower lobe } & Upper lobe \\
\hline 1 & $\begin{array}{l}\text { Zeiss integrating } \\
\text { eyepiece }\end{array}$ & $\times 200$ & 120 & 141 & 98 \\
\hline 2 & $\begin{array}{l}\text { Projected } 16 \text { square } \\
\text { grid }\end{array}$ & $\times 200$ & 145 & 150 & 117 \\
\hline 3 & Photographic print & $\times 67$ & 128 & 118 & 96 \\
\hline
\end{tabular}

RIGHT LUNGS (CONTROL AND AFTER PNEUMONECTOMY) The morphometric parameters for these lungs are shown in Table 4. In control right lungs, lung volume and mean air space dimensions $\left(\mathrm{L}_{\mathrm{m}}\right)$ increased with gain in body weight and, with the exception of rabbits $1.0 \mathrm{~kg}$ in weight, the total number of alveoli per right lung remained constant at about $79 \times 10^{6}$. The data for right lungs at different time periods after left pneumonectomy are shown in the lower part of $\triangle$ Table 4 and a graphical representation of a portion is of the same data is seen in Figure 2. Alveolar number/ $\overrightarrow{0}$ $\mathrm{cm}^{3}\left(\mathrm{~N}_{\mathrm{va}}\right)$ and $\mathrm{S}_{\mathrm{va}}$ decreased with time and mean air-space dimensions $\left(\mathrm{L}_{\mathrm{m}}\right)$ and $\mathrm{V}_{\mathrm{vad}}$ increased (ie, the $\overrightarrow{\vec{\omega}}$ average width increased from $166 \mu \mathrm{m}$ to $205 \mu \mathrm{m}$ ), the former pair producing a mirror-image of the latter pair.

As mean air-space dimensions increased, the : volume density of alveolar septal tissue decreased from $18 \%$ to $12 \%$. Measurements of greatest depth and diameter obtained from alveolar tracings of $1.0 \mu \mathrm{m}$ sections of the left lung and from the lung of the same rabbit killed eight weeks after pneumonectomy indicated variation in both the depth of the alveoli and their diameter in respect to the location of the tissue slice, but no consistent pattern was observed. In this right lung the largest alveoli were found in the upper lobe (Table 2). Lung volume approximated to that of the combined volumes of left and right lungs of animals of similar body weight. The non-parenchyma for post-pneumonectomy right lungs was reduced by $2.1 \%$ to $11.62 \%(\mathrm{P}<0.05)$.

To assist in the interpretation of the lung changes,

Table 3 Comparison of mean air-space diameters derived from mean linear intercept $\left(L_{m}\right)$ values and projected alveolar tracings

\begin{tabular}{|c|c|c|c|c|}
\hline \multirow{2}{*}{\multicolumn{2}{|c|}{ Method }} & \multirow[t]{2}{*}{ Magnification } & \multicolumn{2}{|c|}{ Mean air-space dia. $(\mu m)$} \\
\hline & & & Left lung & Right lung* \\
\hline & $\begin{array}{l}\text { Mean linear intercept }\left(\mathrm{L}_{\mathrm{m}}\right)(60 \text { fields/lung) } \\
\text { Tracings of projected alveoli ( } 45 \text { tracings/lung) }\end{array}$ & $\begin{array}{r}\times 400 \\
\times 400\end{array}$ & $\begin{array}{l}76 \cdot 8 \pm 2 \cdot 75 \\
69 \cdot 4 \pm 2 \cdot 84 \\
P<0.05\end{array}$ & $\begin{array}{l}108 \cdot 7 \pm 13.69 \\
85 \cdot 0 \pm 6 \cdot 8 \\
P<0.05\end{array}$ \\
\hline
\end{tabular}

*Observed 8 weeks after pneumonectomy.

Mean \pm SD.

Table 4 Estimates of alveolar number, mean linear intecept $\left(L_{m}\right)$, and total air-space surface area $\left(S_{a}\right)$ for right lungs; control and after pneumonectomy (PP)

\begin{tabular}{|c|c|c|c|c|c|}
\hline Body wt $(k g)$ & $V_{p}(m l)$ & $\begin{array}{l}\text { Number of alveoli } \\
\times 10^{-6} / \mathrm{cm}^{3}\end{array}$ & $\begin{array}{l}\text { Total no. of alveoli } \\
\times 10^{-6}\end{array}$ & $L_{m}(\mu m)$ & $S_{a} m^{2}$ \\
\hline $\begin{array}{l}1 \cdot 0 \\
2 \cdot 8 \\
3 \cdot 8 \\
4 \cdot 3\end{array}$ & $\begin{array}{l}15 \cdot 6 \\
30 \cdot 1 \\
47 \cdot 0 \\
42 \cdot 2\end{array}$ & $\begin{array}{l}1.84 \text { (control) } \\
2.67 \quad,, \\
1.40 \quad, \\
1.83 \quad,\end{array}$ & $\begin{array}{l}28 \cdot 6 \\
80 \cdot 3 \\
77 \cdot 6 \\
79 \cdot 1\end{array}$ & $\begin{array}{l}73 \cdot 7 \\
64 \cdot 6 \\
66 \cdot 7 \\
76 \cdot 4\end{array}$ & $\begin{array}{l}0 \cdot 720 \\
1 \cdot 584 \\
2 \cdot 397 \\
1 \cdot 878\end{array}$ \\
\hline $\begin{array}{l}3 \cdot 2 \\
3 \cdot 1 \\
3 \cdot 4 \\
3 \cdot 9 \\
4 \cdot 0 \\
3 \cdot 8 \\
4 \cdot 2\end{array}$ & $\begin{array}{l}30 \cdot 1 \\
43 \cdot 0 \\
34 \cdot 7 \\
66 \cdot 0 \\
65 \cdot 3 \\
77 \cdot 0 \\
65 \cdot 0\end{array}$ & $\begin{array}{l}3 \cdot 64(2 \text { wk PP) } \\
2 \cdot 14(8) \\
2 \cdot 03(9) \\
1 \cdot 82(10) \\
1 \cdot 69(11) \\
1 \cdot 30(12) \\
1 \cdot 20(18)\end{array}$ & $\begin{array}{r}109 \cdot 7 \\
92 \cdot 2 \\
70 \cdot 5 \\
120 \cdot 5 \\
98 \cdot 5 \\
85 \cdot 4 \\
72 \cdot 9\end{array}$ & $\begin{array}{l}67 \cdot 2 \\
72 \cdot 7 \\
85 \cdot 8 \\
87 \cdot 4 \\
95 \cdot 3 \\
89 \cdot 8 \\
96 \cdot 9\end{array}$ & $\begin{array}{l}1 \cdot 522 \\
2 \cdot 010 \\
1 \cdot 374 \\
2 \cdot 559 \\
2 \cdot 331 \\
2 \cdot 913 \\
2 \cdot 282\end{array}$ \\
\hline
\end{tabular}

$\mathrm{V}_{\mathrm{p}}=$ lung volume corrected for $\%$ non-parenchyma. 


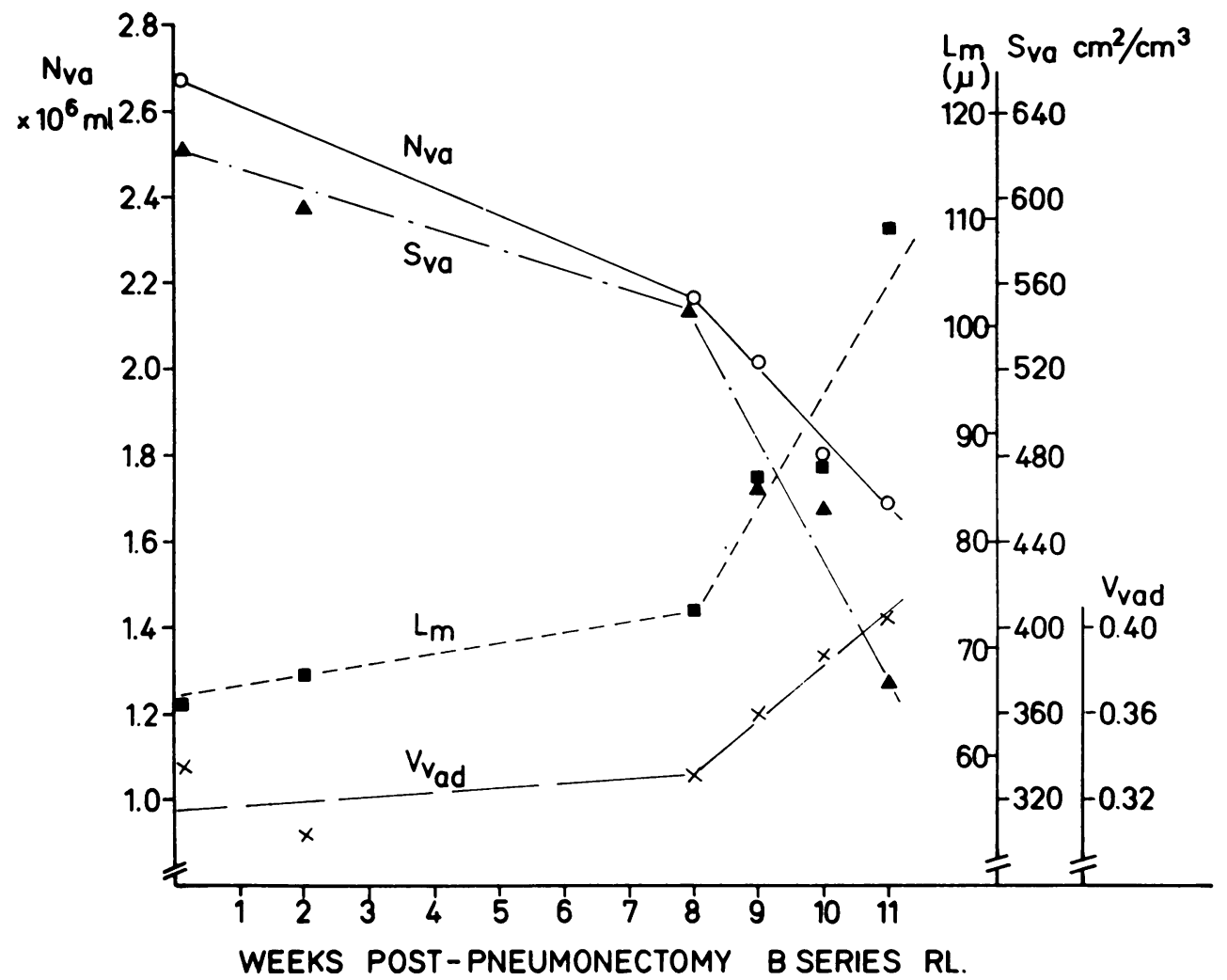

Fig. 2 Graphical representation of morphometric data from a series of right lungs analysed at different time periods after pneumonectomy. The fall in alveolar number $\left(N_{v a}\right)$ and alveolar surface density $\left(S_{v a}\right)$ and rise in mean linear intercept $\left(L_{m}\right)$ and volume density of alveolar duct $\left(V_{v a d}\right)$ have a'mirror-image' relationship.

lungs from normal rabbits ranging in body weight from 1.0 to $9.0 \mathrm{~kg}$ were processed and morphometric data were obtained. A bimodal plot of these normal paired lungs in terms of interalveolar distance $\left(\mathrm{L}_{\mathrm{m}}\right)$ corrected for changes in lung volume, that is, $\mathrm{L}_{\mathrm{m}} /{ }^{3} \sqrt{\triangle_{\mathrm{V}_{\mathrm{L}}}}$ against body weight, is shown in Figure 3 . In animals of about $4.0 \mathrm{~kg}$ in weight ( $>4$ months in age) the interalveolar distance levels off, suggesting no further increase in the number of alveoli. However, when the total number of alveoli $\left(\mathbf{N}_{\mathrm{A}}\right)$ is plotted against body weight (Fig. 4) there appears to be a general increase in the numbers of alveoli for whole lungs. Also shown in Fig. 4 are the total numbers of alveoli for right lungs after pneumonectomy, which are seen to vary considerably within a relatively close range of body weights.

In paired lungs (Fig. 5, closed circles) the total surface area $\left(\mathbf{S}_{\mathbf{a}}\right)$ increases directly with lung volume whereas, in post-pneumonectomy right lungs (crosses), $S_{a}$ increases as the two-thirds power of the lung volume, ie, the $S_{\mathrm{a}}$ values for right lungs 'fit' the paired lung slope at two-thirds the lung volume (dotted lines). All right lungs other than the two with the lowest volumes are eight or more weeks after pneumonectomy.

Enlargement of the lungs of normal rabbits due to natural growth is accompanied by an early increase in the number of alveoli (Fig. 4) and a rise in the volume density of alveolar ducts (Table 5). Alveolar size as estimated by measurement of intercepts $\left(L_{m}\right)$ within the range of body weights investigated is fairly constant, as is the surface area of whole lungs from older animals of $5 \cdot 1$ to $9 \cdot 0 \mathrm{~kg}$ in weight (Table 5).

\section{ELECTRON MICROSCOPY}

A comparison of morphometric data derived from a left lung removed at operation (day 0 ) and the corresponding right lung removed at necropsy 10 weeks later is shown in Table 6 . Changes in the volume densities of different components of the parenchyma 


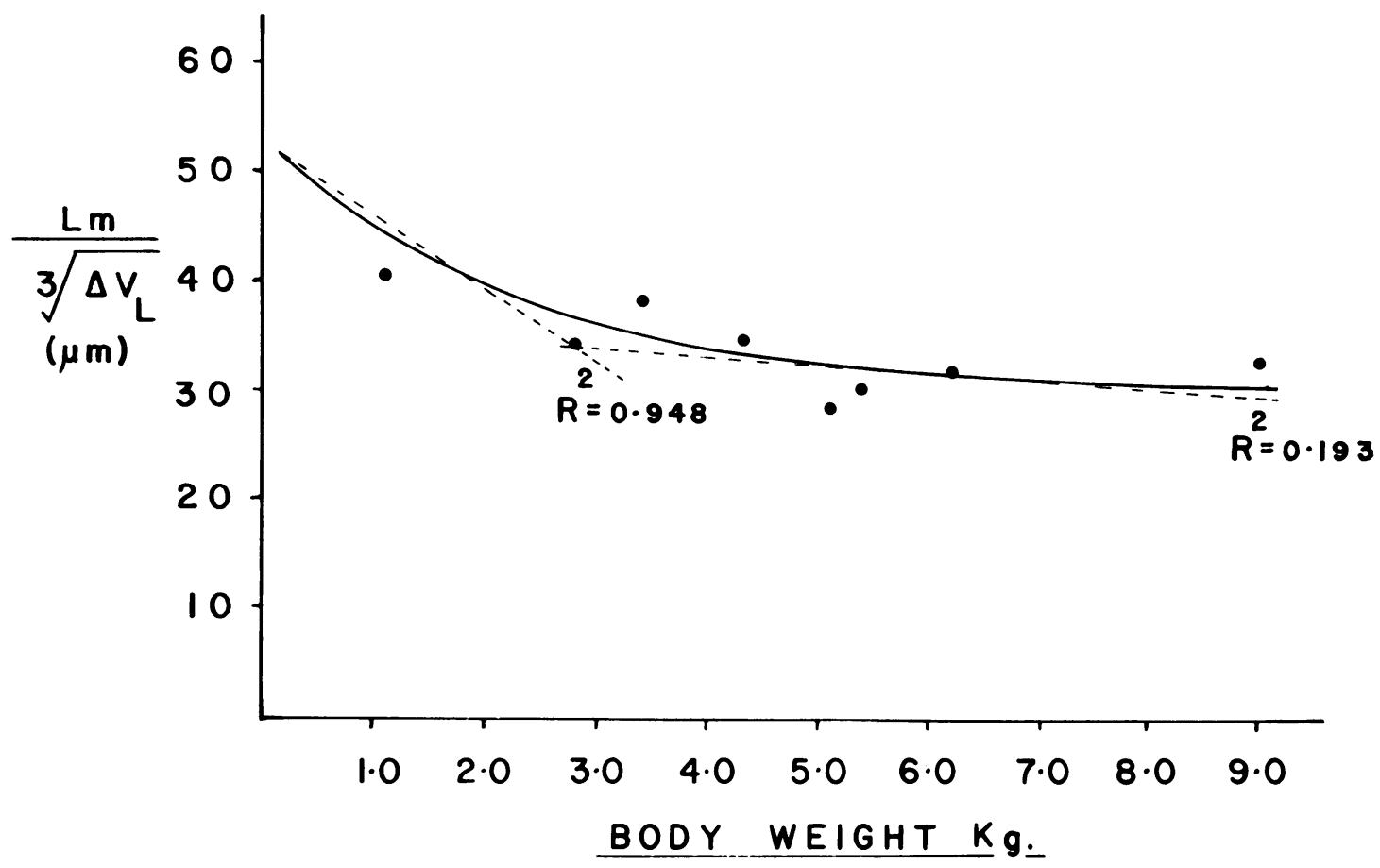

Fig. 3 A plot of interalveolar wall distance $\left(L_{m} / 3 \sqrt{\triangle V_{L}}\right)$ against body weight corrected for increases due to lung inflation. Values are fairly constant at about $4.0 \mathrm{~kg}$ and beyond. Dotted lines are linear regressions.

Table 5 Morphometric parameters of parenchyma tissue from the lungs of rabbits of different body weights

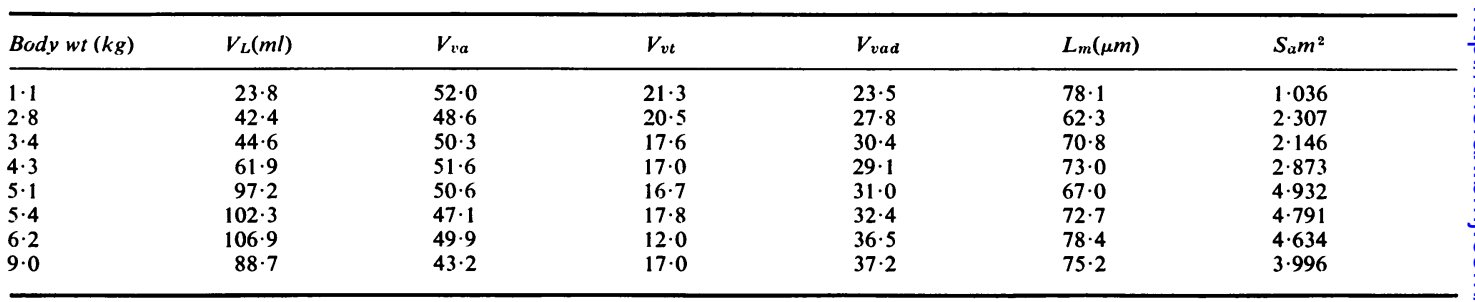

$\mathrm{V}_{\mathrm{va}}=$ volume density of air space $(\%) ; \mathrm{V}_{\mathrm{vt}}=$ volume density of alveolar tissue $(\%) ; \mathrm{V}_{\mathrm{vad}}=$ volume density of alveolar ducts $(\%) ; \mathrm{L}_{\mathrm{m}}=$ mean linear intercept $(\mu \mathrm{m}) ; \mathbf{S}_{\mathrm{a}}=$ total air-space surface area.

are seen as well as differences in air-blood barrier dimensions.

The volume densities of combined air-space (alveoli and alveolar ducts) estimated by light microscopy was $0.73(73 \%)$ and by electron microscopy (Table 6) $0.74(74 \%)$. Air-space surface areas calculated for right lungs by use of electron microscopy were larger than those derived by use of light microscopy $\left(3.5 \mathrm{~m}^{2} v 2.4 \mathrm{~m}^{2}\right)$. For left lungs, the areas were correspondingly $1.1 \mathrm{~m}^{2} v 0.71 \mathrm{~m}^{2}$.

\section{Lung casts}

A photograph of a polyester resin cast of a right lung nine weeks after pneumonectomy from a rabbit of $3.6 \mathrm{~kg}$ in body weight is shown in Figure 6 . This cast and casts of three control lungs from animals of similar body weight were measured with respect to diameter and length of the axial airway. Overall the axial airway from the pneumonectomy cast was $5.0 \mathrm{~mm}$ longer than two of the control casts and $2.0 \mathrm{~mm}$ longer than the remaining control. However, axial airway diameters of the pneumonectomy cast were not significantly different from those of the controls. Whether this difference in axial length is common to all post-pneumonectomy right lungs remains to be verified. In any event, the agreement between control and pneumonectomy right lungs in 


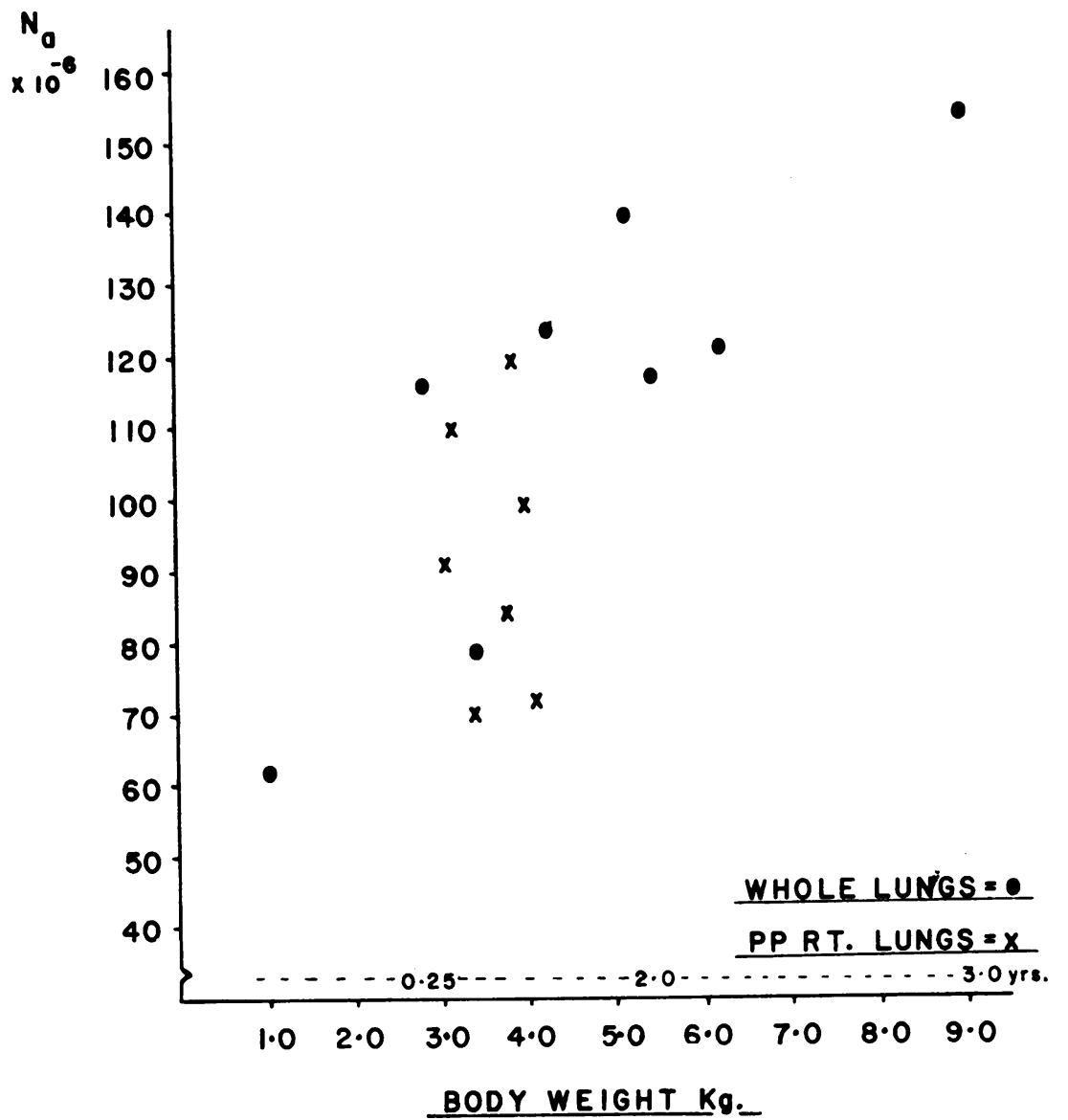

Table 6 Morphometric data obtained by electron microscopy of lungs before and after pneumonectomy $(P P)$

\begin{tabular}{|c|c|c|}
\hline Morphometric parameters & $\begin{array}{l}\text { Dav } 0 \\
\text { left lung }\end{array}$ & $\begin{array}{l}10 \text { weeks } P P \\
\text { right lung }\end{array}$ \\
\hline Volume density-air space & $0 \cdot 74$ & $0 \cdot 84$ \\
\hline ,, $\quad, \quad$-capillaries & 0.06 & 0.05 \\
\hline , -alveolar wall & $0 \cdot 20$ & $0 \cdot 11$ \\
\hline ., -epithelium & $0 \cdot 25$ & $0 \cdot 30$ \\
\hline,$\quad$-interstitium & 0.40 & 0.40 \\
\hline$\because \quad \quad \because \quad$-endothelium & $0 \cdot 35$ & 0.30 \\
\hline Surface density-alveoli & $854 \mathrm{~cm}^{2} / \mathrm{cm}^{3}$ & $588 \mathrm{~cm}^{2} / \mathrm{cm}^{3}$ \\
\hline Arithmetic mean-alveolar wall & $2.9 \mu \mathrm{m}$ & $2 \cdot 15 \mu \mathrm{m}$ \\
\hline Harmonic mean-alveolar wall & $0.85 \mu \mathrm{m}$ & $0.85 \mu \mathrm{m}$ \\
\hline Thickness of epithelium & $0.68 \mu \mathrm{m}$ & $0.53 \mu \mathrm{m}$ \\
\hline ,, ,, interstitium & $1 \cdot 15 \mu \mathrm{m}$ & $0.87 \mu \mathrm{m}$ \\
\hline$, \quad,$, endothelium & $1 \cdot 26 \mu \mathrm{m}$ & $0.78 \mu \mathrm{m}$ \\
\hline Absolute surface area & $0.996 \mathrm{~m}^{2}$ & $3.50 \mathrm{~m}^{2}$ \\
\hline
\end{tabular}

terms of airway diameters was remarkably close and confirms the usefulness of this casting technique.
Fig. 4 A plot of the total number of alveoli $\left(N_{a}\right)$ against body weight or age for whole lungs $(0)$ and right lungs after pneumonectomy $(x)$. Alveolar number appears to increase with age and some right lungs have as many alveoli as certain whole lungs. 


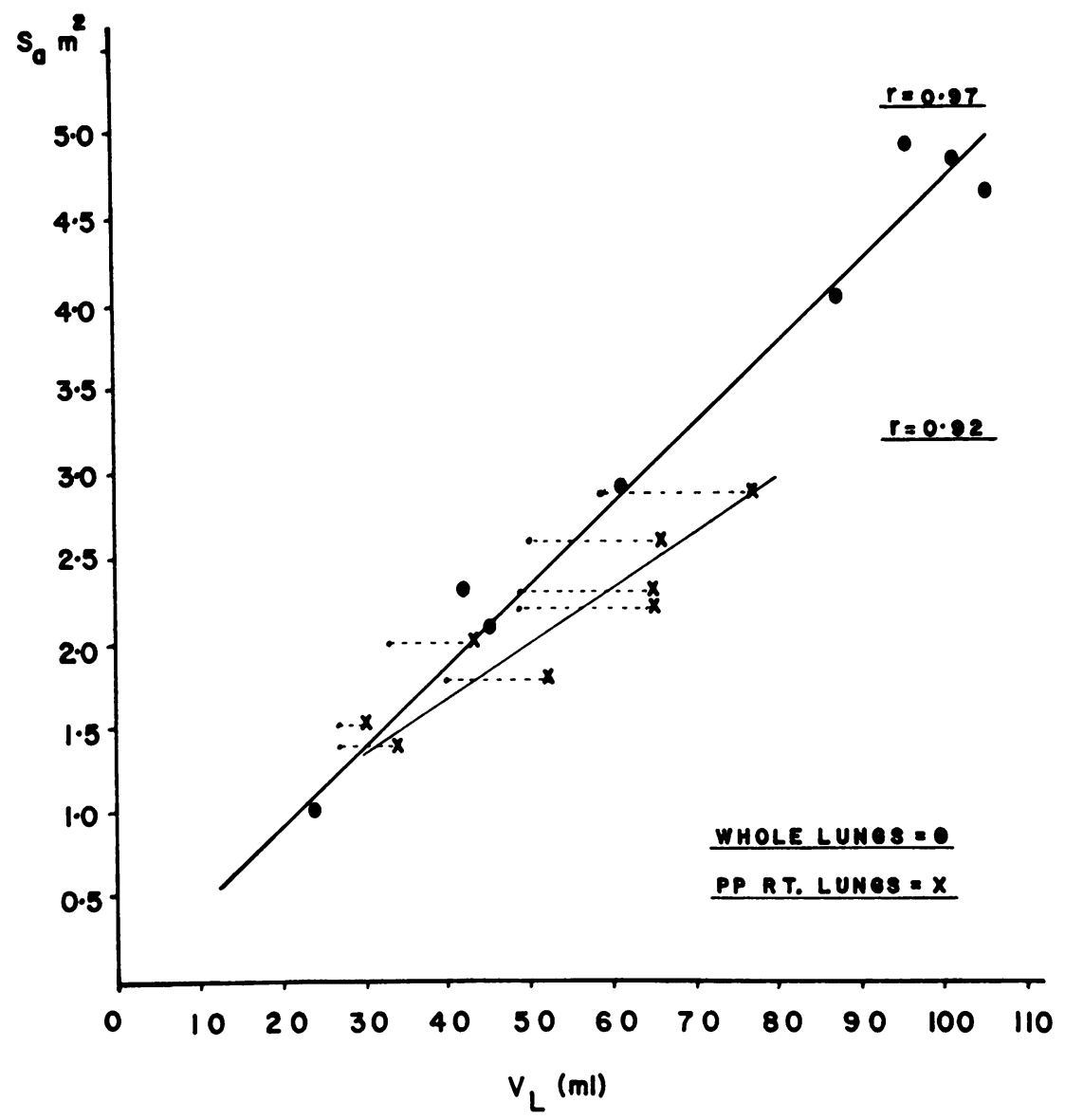

accurate determination is based upon statistical probabilities, and with respect to point-counting the degree of accuracy obtained is dependent upon the total number of counts made. In the present study the volume densities were based on 500 to 700 points per section. From the data of Weibel (1963) the expected error is about $4 \%$ to $8 \%$, depending upon the frequency of the component. Even so, much depends upon the discriminatory powers of the observer. In our work, all morphometric determinations were made by a single observer.

The question of the shrinkage of lung tissue after fixation and embedding has periodically received attention, and fixation constants have been derived for particular systems (Dunnill, 1962; Weibel and Knight, 1964; Burri et al., 1974). Provided that care is taken in the choice of fixatives, buffers, and the osmolality of the final solutions, the changes in tissue dimensions, particularly with resin embedding, are less than $5 \%$ (Weibel and Knight, 1964). The linear conversion coefficient for glutaraldehyde/ osmium fixed tissue in the present study was identical with that of Weibel and Knight (1964), that is, 1.05 with the use of $70 \%$ ethanol as the initial dehydrating agent.

In animal experiments involving pneumonectomy, comparisons are often difficult because of the lack of information concerning the breed, sex, age, and body weight of the animal employed in the study. In many cases, only the term 'adult' is used to characterise the animal.

The body weight of the animals used in our study ranged from $1.0 \mathrm{~kg}$ to $9.0 \mathrm{~kg}$ which, in age, is from about 2 months to 3 years. The rabbits termed adult by Short (1952) had a $V_{L}$ of $43 \mathrm{ml}$ and a $S_{\mathrm{a}}$ of $2.3 \mathrm{~m}^{2}$, which would correspond to our rabbits of $3.8 \mathrm{~kg}$. Seŕy et al. (1969) used adult rabbits with a mean $\mathrm{V}_{\mathrm{L}}$ of $62 \mathrm{ml}$ and a $S_{\mathrm{a}}$ of $2.53 \mathrm{~m}^{2}$, which would correspond to our rabbits of $4 \cdot 3 \mathrm{~kg}$.

It has been shown by use of a variety of animal species that, irrespective of whether the right lung or left lung is removed, the stimulus to the remaining 


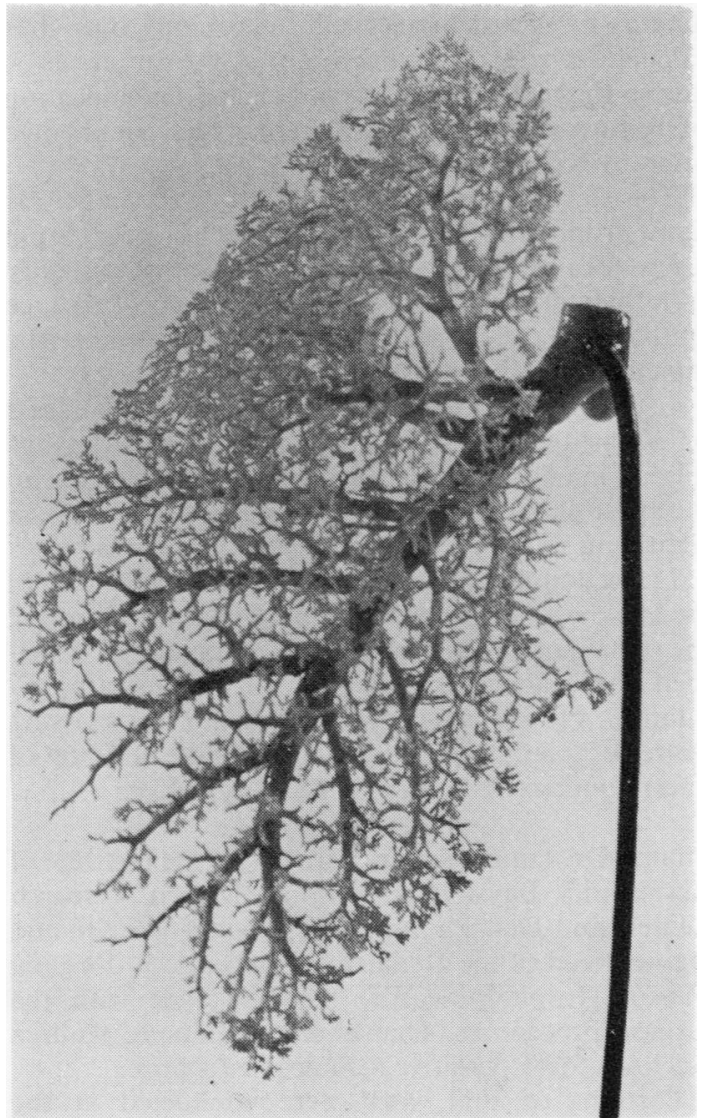

Fig. 6 A resin corrosion cast (partially trimmed) of a right lung nine weeks after pneumonectomy.

lung results in a compensatory increase in lung volume. Generally, the remaining lung doubles in volume or is equal to the combined volume of left and right lungs within 4 to 10 weeks. Our results (Tables 1 and 4 ) are consistent with this. It should be recalled that, although either lung can be removed, removal of the right lung reduces total lung tissue abruptly by about two-thirds. In either event the metabolic needs are apparently met since Nattie et al. (1974) found in rats that hypoxia was absent 24 hours after surgery and Cournand et al. (1950) noted in humans that alveolar ventilation/perfusion relationships after pneumonectomy showed that the vascular bed of the remaining ling was able to accommodate a twofold increase in pulmonary blood flow in a normal manner.

With a rapidly changing residual lung the advantage of morphometry is that relatively small changes not readily detectable by visual examination can be determined. The pictorial and calculated data shown in Fig. 1 support this contention. The results (Tables 1 and 4; Figs. 1 and 2) confirm the findings of Šery et al. (1969) and show that after pneumonectomy the increase in volume of the remaining lung required to fill an enlarged thoracic space caused by a displaced mediastinum is satisfied almost entirely by a substantial increase in mean linear intercept and in the volume density of alveolar ducts. Given such factors as variations in age, body weight, and lung volume (Šeŕy et al. removed the right lung), as well as differences in fixation, sampling, and processing of tissue, the values obtained from the two studies are remarkably close. For example, the amount of nonparenchyma calculated for adult rabbits from measurements by light microscopy (Šeŕy et al., 1969) was $12.43 \%$. In our study, it was $11.89 \%$ obtained by the use of $4 \mathrm{~mm}$ tissue slices and $13.72 \%$ by use of $1.0 \mu \mathrm{m}$ sections. Also, in adult animals before and after pneumonectomy, in both studies the volume density of alveolar duct air-space increased from $32.47 \%$ to $47.5 \%$ (Šeŕy), an increase of $45 \%$; and in our study from $30.2 \%$ to $40.8 \%$, an increase of $33 \%$ (Fig. 1). Seŕy et al. (1969), however, did not estimate the mean interalveolar distance for those lungs but did estimate the mean surface area of air-space.

Estimates relating to either the numbers of alveoli/ $\mathrm{cm}^{3}$ or the absolute number are subject to considerable errors. The first is a subjective one-of what, in any plane of section, constitutes an alveolus (Burri et al., 1974), and the second is the problem of interanimal variation. A table by Weibel (1963) shows that, in human lung, total alveolar counts range from 75 to 775 million, and Thurlbeck (1975) has estimated the range in the adult to be from 175 to 530 million. We found similar variability in the rabbit not only in whole lungs but also in the right lung after left pneumonectomy (Fig. 4). In some instances in these right lungs the calculated total number of alveoli equals that of both lungs in animals of similar body weight, thus suggesting some degree of alveolar multiplication. However, if the average number of alveoli $/ \mathrm{cm}^{3}$ of tissue for whole lungs irrespective of body weight $\left(2.31 \pm 0.46 \times 10^{6}\right)$ and of right lungs $>8$ weeks post-pneumonectomy $(1 \cdot 70 \pm 0.38 \times$ $\left.10^{6}\right)$ are compared, then the latter are significantly lower $(P<0.05)$. This suggests that after pneumonectomy in the rabbit little or no increase in alveolar number occurs. Additional errors in counting alveoli concern inter-observer variation and possibly the method used, although the three methods used in our study were within the expected error of $10 \%$.

If the increase in lung volume occurs by simple distension of existing tissue we may ask how this affects the surface cells of a single alveolus. Meyrick and Reid (1970) estimated that in human lungs the proportion of type I alveolar lining cells to type II 
cells/alveolus is in the ratio of $4: 6$, giving a total of 113 type I cells and 170 type II cells/alveolus. Using Reid's figures of $54 \mu \mathrm{m}$ diameter and $2290 \mu \mathrm{m}^{2}$ for the type I cell and $9 \mu \mathrm{m}$ and $63 \mu \mathrm{m}^{2}$ for the type II cell, it was calculated that with the same proportions a single rabbit alveolus of $71.25 \mu \mathrm{m}$ diameter and a surface area of $15950 \mu \mathrm{m}^{2}$ would accommodate about six type I cells and nine type II cells. Furthermore, if after pneumonectomy the diameter of a single alveolus was increased to $84.25 \mu \mathrm{m}$, then either the surface area of the cells would have to increase by $40 \%$ or an increase in the number of cells from 15 to 22 would be required. On present concepts it appears that the type II cell would be the source of the new cells. The requirement for a cell to expand by $40 \%$ would mean an increase in diameter of about $10 \mu \mathrm{m}$ for the type I cell and $1.6 \mu \mathrm{m}$ for the type II cell. Alternatively, a change in cell shape (surface to volume ratio) may be all that is required. A study is under way to attempt to estimate the average number of type I and type II cells per alveolus and the dimensions of the cells.

Cowan and Crystal (1975) suggest that in the adult rabbit the observed increase in cell number (ie, on the basis of increases in dry weight, DNA, protein, and hydroxyproline) one month after left pneumonectomy reflects alveolar hypertrophy and/or hyperplasia. All four values were increased by nearly $100 \%$ over the control estimates. Obliteration of the empty hemithorax with wax results in the suppression of both DNA and collagen synthesis in the remaining lung.

Morphometric analysis of the components of the air-blood barrier by electron microscopy showed as expected a thinning of the barrier after pneumonectomy (Table 6). In keeping with the results obtained by light microscopy, the surface density of alveoli $\left(\mathbf{S}_{\mathrm{va}}\right)$ was also reduced. Electron microscopy showed that the relative thicknesses of components of the barrier were reduced after pneumonectomy as was the arithmetic mean $(\bar{\tau})$ thickness. The harmonic mean $\left(\bar{\tau}_{\mathrm{h}}\right)$ however, did not change. Estimates of barrier thickness obtained by Weibel (1972) for the

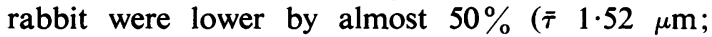

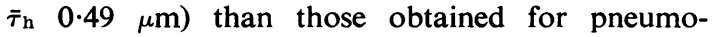
nectomised rabbits in the present study $(\bar{\tau} 2.15 \mu \mathrm{m}$; $\left.\bar{\tau}_{\mathrm{h}} 0.85 \mu \mathrm{m}\right)$. Why this was so is not clear. Additional measurements of other lungs produced values of a similar order. Interstitial oedema appeared not to be involved, and the volume densities of epithelium, interstitium, and endothelium were the same as those for the rat. The measurement of normal rat lungs using the same methodology produced results very close to those obtained by Weibel (1972) and Burri et al. (1974) for this species. Clearly, additional analyses are required to resolve this problem.

The relative increase in total surface area of the lung as estimated by electron microscopy over that calculated from light microscopy measurements is due to the higher resolving power and magnification of the former technique, and this has been commented upon by Keller et al. (1976).

The electron microscopic appearance of alveolar tissue from post-pneumonectomy lungs, apart from a few focal areas of swollen cytoplasm of capillary endothelium, was relatively normal. Type I surface epithelium and type II cells with characteristic lamellated bodies were similar to control lungs.

In conclusion it may be said that the overall effects of left pneumonectomy in the adult rabbit are those of dilatation of alveoli and alveolar ducts in accord with a substantial increase in the volume of the remaining right lung.

Dilatation of existing alveoli causes a reduction in the thickness of the alveolar septal tissue. Structurally, the remaining lung is somewhat compromised. What then is its fate in the presence of gaseous air pollutants? Preliminary findings indicate a surprising degree of tolerance, although age and the addition of intermittent exercise may be deciding factors.

I thank Dr. James Martin, Director of the Institute of Respiratory Physiology, Virginia Mason Research Center, and Drs. Phillip Jolly, David Enwright, and Daniel Reed of the Department of Surgery, Virginia Mason Hospital, Seattle, for assistance with the surgical procedures. Thanks are also due to Andrea Erickson for superlative technical assistance.

Portions of this work were conducted at the Universities of London, Berne, and Oxford during my tenure of a Josiah Macy Foundation Scholarship. For much advice and help freely given I wish to thank Professor Lynne Reid, Dr. David Tompsett, Professor Ewald Weibel, Dr. Peter Burri, and Dr. Michael Dunnill. This work was supported by grants from the National Institute of Environmental Health Sciences No: ES 0149 and the National Heart and Lung Institute No: HL 14152.

\section{References}

Boatman, E. S., and Lowe, D. (1971). Photographic mapping of a tissue surface to locate fields for electron microscopy; mouse lung. Stain Technology, 46, 63-69.

Bremer, J. L. (1937). The fate of the remaining lung tissue after lobectomy or pneumonectomy. Journal of Thoracic Surgery, 6, 336-343.

Buhain, W. J., and Brody, J. S. (1973). Compensatory growth of the lung following pneumonectomy. Journal of Applied Physiology, 35, 898-902.

Burri, P. H., Dbaly, J., and Weibel, E. R. (1974). The postnatal growth of the rat lung. 1. Morphometry. Anatomical Record, 178, 711-730. 
Cournand, A., Riley, R. L., Himmelstein, A., and Austrian, R. (1950). Pulmonary circulation and alveolar ventilation-perfusion relationships after pneumonectomy. Journal of Thoracic Surgery, 19, 80-116.

Cowan, M. J., and Crystal, R. G. (1975). Lung growth after unilateral pneumonectomy: quantitation of collagen synthesis and content. American Review of Respiratory Diseases, 111, 267-277.

Donaldson, H. H. (1924). The Rat. (Memoirs of the Wistar Institute, no. 6), 2nd edition. Wistar Institute of Anatomy and Biology, Philadelphia.

Dunnill, M. S. (1962). Quantitative methods in the study of pulmonary pathology. Thorax, 17, 320-328.

Gnävi, M., Pansa, E., and Anselmetti, G. (1970). L'accrescimento e la rigenerazione del polmone. Minerva Chirurgica, 25, 1491-1504.

Haasler, F. (1892). Ueber compensatorische Hypertrophie der Lunge. Virchows Archiv für pathologische Anatomie und Physiologie, 128, 527-536.

Keller, H. J., Friedli, H. P., Geher, P., Bachofen, M., and Weibel, E. R. (1976). The effects of optical resolution on the estimation of stereological parameters. National Bureau of Standards Special Publication 431. Proceedings of the 4th International Congress for Stereology, Gaithersburg, Md., 1975.

Longacre, J. J., and Johansmann, R. (1940). An experimental study of the fate of the remaining lung following total pneumonectomy. Journal of Thoracic Surgery, 10, 131-149.

Meyrick, B., and Reid, L. (1970). The alveolar wall. British Journal of Diseases of the Chest, 64, 121140.

Nattie, E. E., Wiley, C. W., and Bartlett, D., Jr. (1974). Adaptive growth of the lung following pneumonectomy in rats. Journal of Applied Physiology, 37, 491-495.

Reid, L. (1967). The embryology of the lung. In CIBA Foundation Symposium on Development of the Lung. edited by A. V. S. de Reuck and R. Porter, p. 109. Little, Brown Boston. Churchill. London.

Rienhoff, W. F., Jr., Reichert, F. L., and Heuer, G. J. (1935). Compensatory changes in the remaining lung following total pneumonectomy. Bulletin of the Johns Hopkins Hospital, 57, 373-383.

Seŕy, Z., Keprt, E., and Obručnik, M. (1969). Morphometric analysis of late adaptation of the residual lung following pneumonectomy in young and adult rabbits. Journal of Thoracic and Cardiovascular Surgery, 57, 549-557.

Short, R. H. D. (1952). Aspects of comparative lung growth. Proceedings of the Royal Society Series B, 140, 432-441.

Thurlbeck, W. M. (1975). Postnatal growth and development of the lung. American Review of Respiratory Diseases, 111, 803-844.

Tomkeieff, S. I. (1945). Linear intercepts, areas and volumes. Nature, 155, 24.

Tompsett, D. H. (1970). Casts from the lung. In Anatomical Techniques, 2nd edition, p. 123. Livingstone, Edinburgh.

Weibel, E. R. (1963). Morphometry of the Human Lung, Springer, Berlin, Academic Press, New York.

Weibel, E. R. (1970a). An automatic sampling stage microscope for stereology. Journal of Microscopy, 91, 1-18.

Weibel, E. R. (1970b). Morphometric estimation of pulmonary diffusion capacity: 1 model \& method. Respiration Physiology, 11, 54-75.

Weibel, E. R. (1972). Morphometric estimation of pulmonary diffusion capacity. V. Comparative morphometry of alveolar lungs. Respiration Physiology, 14, $26-43$.

Weibel, E. R., and Gomez, D. M. (1962). A principle for counting tissue structures on random sections. Journal of Applied Physiology, 17, 343-348.

Weibel, E. R., and Knight, B. W. (1964). A morphometric study on the thickness of the pulmonary airblood barrier. Journal of Cell Biology, 21, 367-396.

Requests for reprints to: Dr. Edwin S. Boatman, Associate Professor of Environmental Health and Pathobiology, School of Public Health and Community Medicine, Department of Environmental Health, SC34, University of Washington, Seattle, Washington, 98195, USA. 